\title{
sciforum
}

Conference Proceedings Paper

\section{Nutrient and Water Use Efficiency at Leaf Level of Cucumber Plants under Contrasting Soil Nutrient and Lignosulfonate Level}

\author{
Elena Ikkonen ${ }^{1, *}$, Svetlana Chazhengina ${ }^{2}$ and Marija Jurkevich ${ }^{1}$ \\ 1 Institute of Biology, Karelian Research Center RAS, Puskinskaja, 11, 185610 Petrozavodsk, Russia; \\ likkonen@gmail.com \\ 2 Institute of Geology, Karelian Research Center RAS, Puskinskaja, 11, 185610 Petrozavodsk, Russia; \\ chazhengina@mail.ru \\ * Correspondence: likkonen@gmail.com; Tel.: +7-911-0543-124
}

Published: 30 November 2020

\begin{abstract}
To reduce the use of commercial conventional inorganic fertilizers the possibility of using pulp and paper industry wastes in agriculture as an alternative source of nutrients is recently under study and discussion. This work aimed to evaluate the effect of sodium lignosulfonate application to soil on photosynthetic leaf nutrient $(\mathrm{N}, \mathrm{P}, \mathrm{K}, \mathrm{Ca}, \mathrm{Mg}, \mathrm{Fe}$, and $\mathrm{Mn}$ ) and water use efficiency. A pot culture experiment was conducted with cucumber seedlings, using five lignosulfonate concentrations $(0,1,2.5,5$, and 10 vol. \%) in sandy soil under sufficient or low nutrient availability for plants. The impact of nutrient availability on plant physiological traits was stronger than the lignosulfonate impact. Under the condition of sufficient nutrient availability, the lignosulfonate application decreased $\mathrm{N}, \mathrm{P}, \mathrm{K}, \mathrm{Ca}, \mathrm{Mg}$, and Fe use efficiency, increased Mn use efficiency, and did not change water use efficiency. The decrease of nutrient use efficiency was connected with both photosynthetic rate decrease and leaf nutrient content increase. The decline in soil nutrient availability caused a decrease in nutrient and water use efficiency. Under low nutrient availability, soil lignosulfonate tended to increase nutrient and water use efficiency, but it was not successful to eliminate the negative effects of soil nutrient deficiency on plant growth, photosynthetic processes, and efficiency of nutrient use.
\end{abstract}

Keywords: Cucumis sativus; pulp and paper industry waste; plant biomass; photosynthesis; leaf macronutrient concentration

\section{Introduction}

For agricultural soils with low natural fertility, an application of a wide range of nutrient-rich substrates are recently under discussion [1-3]. To reduce the use of commercial conventional inorganic fertilizers the possibility of using pulp and paper industry wastes in agriculture as an alternative source of nutrients is also under study [4,5]. Lignosulfonates (LSs), which are by-products from the paper industry, can be applied as a soil conditioner and chelate fertilizer $[6,7]$. Recent studies have shown that LSs can be used as stimulants in plant growth and fructification $[8,9]$, but Stapanian and Shea [10], on the contrary, did not found a stimaulated effect of LS on plant biomass and did show that it was decreased at high content of soil LS. It is assumed that LSs could have a positive effect on the photosynthetic process [11], but no information is available concerning the effects of lignosulfonate application to soils on plant photosynthetic activity. Moreover, it is uncertain whether the impact of LSs on plant $\mathrm{CO}_{2}$ assimilation is affected by soil nutrient availability for plants. A range of elements play a critical role in plant photosynthetic processes and the improvement of soil chemical properties by LS, as was shown by Islas-Valdez et al. [6], especially for the soils with low natural fertility, hypothetically could improve nutrient accumulation by plant and enhance photosynthetic activity. But how this affects the photosynthetic efficiency of nutrient using 
The 1st International Electronic Conference on Plant Science, 1-15 December 2020

remains unclear. This study aimed to evaluate the effects of sodium LS application to sandy soil on physiological responses such as plant growth, leaf nutrient (N, P, K, Ca, Mg, Fe, and Mn) accumulation, photosynthesis, nutrient and water use efficiency at the leaf level of Cucumis sativus seedlings. Comparisons were made using plants grown under contrasting conditions of soil nutrient availability.

\section{Experiments}

\subsection{Substrate Preparation and Plant Growth Conditions}

Sodium LS was mixed with dry sandy soil to achieve its concentration in the substrates, equal 0 , $1.0,2.5,5.0$, and $10 \%(\mathrm{v} / \mathrm{v})$, designated as 0LS, 1LS, 2.5LS, 5LS and 10LS treatments, respectively. The substrates were incubated under constant conditions for 90 days. Cucumber (C. sativus L., var. Kurag) were grown in pots filled with the substrates under controlled conditions of climate chambers $\left(23 / 20^{\circ} \mathrm{C}\right.$ day/night temperature, $70 \%$ relative air humidity, $16-\mathrm{h}$ photoperiod, $300 \mu \mathrm{mol}$ $\mathrm{m}^{-2} \mathrm{~s}^{-1}$ of PPFD). For half of the pots, the nutrient solution (based on $1 \mathrm{~g} \mathrm{l}^{-1} \mathrm{Ca}\left(\mathrm{NO}_{3}\right)_{2}, 0.25 \mathrm{~g} \mathrm{l}^{-1}$ $\mathrm{KH}_{2} \mathrm{PO}_{4}, 0.25 \mathrm{~g} \mathrm{l}^{-1} \mathrm{MgSO}_{4} 7 \mathrm{H}_{2} \mathrm{O}, 0.25 \mathrm{~g} \mathrm{l}^{-1} \mathrm{KNO}_{3}$, a trace quantity of $\mathrm{FeSO}_{4}$ and $\mathrm{pH} 6.2-6.4$, EC 2.0 mS $\mathrm{cm}^{-1}$ ), while for the other half, water was supplied (SNA, sufficient nutrient availability, and LNA, low nutrient availability, respectively).

\subsection{Photosynthetic Parameters and Plant Biomass Measurements}

Gas-exchange parameters $\left(A_{\mathrm{n}}\right.$, net $\mathrm{CO}_{2}$ assimilation; $\mathrm{Tr}$, leaf transpiration rate, and WUE $=A_{\mathrm{n}}$ $\mathrm{Tr}^{-1}$, photosynthetic water-use efficiency) were measured with a portable photosynthesis system (HCM-1000, Walz, Effeltrich, Germany) at leaf temperature of $25^{\circ} \mathrm{C}$ and $1200 \mu \mathrm{mol} \mathrm{m}^{-2} \mathrm{~s}^{-1}$ of PPFD. After the gas exchange measurements, the plants were harvested, separated into organs, and dryed at $70{ }^{\circ} \mathrm{C}$. The LMA values were calculated as leaf mass per unit leaf area.

\subsection{Leaf Chemical Analysis}

Dry leaves were used for chemical analysis. Kjeldahl digestion was applide for the determination of total $\mathrm{N}$ and $\mathrm{P}$. The $\mathrm{N}$ content was determined by the nesslerization of the ammonia, and the $\mathrm{P}$ content was determined by the ammonium molybdate method. Both $\mathrm{N}$ and $\mathrm{P}$ were analyzed by spectrophotometer (SF 2000 OKB Spectrum, Saint-Petersburg, Russia). Total element concentration of $\mathrm{K}, \mathrm{Ca}, \mathrm{Mg}, \mathrm{Fe}, \mathrm{Mn}$, and $\mathrm{Na}$ was determined by spectrophotometric atomic absorption (Shimadzu AA-7000, Kioto, Japan) in the Core Facility "Analytical laboratory" of the Forest Institute of KRC of RAS. Photosynthetic nutrient use efficiency was calculated by dividing area-related $A_{\mathrm{n}}$ by the value of specific leaf element content.

\subsection{Statistical Analysis}

For each treatment, the means \pm SE were determined with at least five and more replicates for the $A_{n}, T r, W U E$, and LMA parameters. For the chemical leaf analysis, we used four seedlings of each treatment grown under the condition of sufficient nutrient availability, but for the seedlings grown under low nutrient availability, all leaves of eight seedlings of each treatment were combined in one sample. To assess the significant difference between the treatments at the $p<0.05$ level, the least significant difference (LSD) of ANOVA was used. The effects of soil LS concentration, nutrient availability, and their interaction were analyzed using a two-way ANOVA. 


\section{Results}

\subsection{Plant Biomass}

With the decline in nutrient availability from SNA to LNA, the total plant and leaf biomass decreased by 18 and 37 times respectively, and LMA increased by 32\% for the 0LS seedlings (Table 1). The two-way ANOVA revealed a significant effect of both nutrition and LS, and their interaction on biomass accumulation and its allocation into organs $(p<0.001)$. While under the SNA conditions, LS application caused a decrease in leaf and total mass of 5LS and 10LS seedlings, under the LNA, the biomass tended to increase $(0.05<p<0.01)$. The $2.5 \mathrm{LS}$ and 5LS seedlings of the SNA treatment had higher LMA values compared to OLS ones, and the LMA values of LNA seedlings increased in accordance with the increase in LS content.

\subsection{Gas exchange Parameters}

The $A_{\mathrm{n}}$ and Tr values were significantly affected by nutrient availability, but not LS application. The decline of nutrient availability for the cucumber seedlings decreased the $A_{n}$ rate, as well as $\operatorname{Tr}$ values (Table 1). Although the two-way ANOVA revealed an insignificant effect of LS application on $A_{\mathrm{n}}$, the LS application significantly decreased the $A_{\mathrm{n}}$ rate for 1LS seedlings grown under SNA. For the LNA seedlings, the $A_{n}$ rate tended to increase in the cases when LS was added to the soil. The LS application did not have a strong effect on Tr for the SNA seedlings, but for the LNA seedlings, the Tr value was the highest in 5LS leaves and the lowest in 0LS ones.

\subsection{Leaf Nutrient Content}

The decline of soil nutrient availability caused an increase in leaf $\mathrm{N}, \mathrm{Fe}$, and $\mathrm{Na}$ content, and a decrease in leaf $\mathrm{P}, \mathrm{K}$, and Mg content for 0LS seedlings (Table 1). According to the two-way ANOVA the effect of LS application was significant for leaf $\mathrm{K}, \mathrm{Ca}, \mathrm{Mg}, \mathrm{Fe}, \mathrm{Mn}$, and $\mathrm{Na}$. The $\mathrm{N}$ and $p$ values were the highest in 1LS leaves among all LS treatments under the SNA condition. Following the increase in soil LS, leaf Na content increased, Mn content decreased, and K content did no change regardless of soil nutrient availability. Under both nutrient levels, the 1LS seedlings had higher and 10LS seedlings had lower leaf concentrations of $\mathrm{Ca}$ and $\mathrm{Mg}$ than the $\mathrm{OS}$ seedling. While the increase in the soil LS concentration decreased Fe content under LNA, this tendency was not recorded for seedlings grown under SNA.

\subsection{Photosynthetic Nutrient Use Efficiency}

For all elements under the study, photosynthetic nutrient use efficiency was lower for LNA than SNA seedlings (Table 1). The LS effect on the use efficiency of elements depended on the soil's ability of nutrients. While for the PNUE, PPUE, PKUE, and PFeUE values, the two-way ANOVA revealed an insignificant effect of the LS treatment $(p>0.05)$, PCaUE, PMgUE, PMnUE, and PNaUE were significantly altered by both LS application and nutrient availability $(p<0.01)$. For the most of studied leaf element concentrations in the LNA seedlings, no significant effect of LS on photosynthetic nutrient use efficiency was observed. The LS application decreased PNUE, PPUE, and PNaUE, respectively, by 74, 114, and 79\% on average among all LS seedlings grown under SNA condition. For the PKUE, PCaUE, PMgUE, and PFeUE values, a significant LS-related decrease was found only for the 1LS and 2.5LS SNA seedlings. Unlike other elements under the study, LS enhanced PMnUE values following the increase in soil LS content from 1LS to 5LS regardless of soil nutrient ability. 
The 1st International Electronic Conference on Plant Science, 1-15 December 2020

Table 1. Mean values of physiological traits, leaf nutrient concentration, and photosynthetic nutrient and water use efficiency of cucumber plants grown on the sandy soil with lignosulfonate concentration of 0 (0LS), 1 (1LS), 2.5 (2.5LS), 5 (5LS) and 10 (10LS)\% under sufficient or low nutrient availability (SNA and LNA, respectively).

\begin{tabular}{|c|c|c|c|c|c|c|c|c|c|c|}
\hline Variables & & & SNA & & & & & LNA & & \\
\hline & OLS & 1LS & $2.5 \mathrm{LS}$ & $5 \mathrm{LS}$ & 10LS & OLS & 1LS & $2.5 \mathrm{LS}$ & 5LS & 10LS \\
\hline Plant DM, g plant ${ }^{-1}$ & $1.96 \pm 0.21 \mathrm{a}$ & $2.08 \pm 0.12 \mathrm{a}$ & $2.03 \pm 0.10 \mathrm{a}$ & $1.80 \pm 0.201 \mathrm{ab}$ & $1.53 \pm 0.12 b$ & $0.11 \pm 0.00 \mathrm{c}$ & $0.17 \pm 0.02 c$ & $0.18 \pm 0.02 \mathrm{c}$ & $0.20 \pm 0.02 \mathrm{c}$ & $0.22 \pm 0.02 \mathrm{c}$ \\
\hline Leaf DM, g plant ${ }^{-1}$ & $1.11 \pm 0.21 \mathrm{ab}$ & $1.31 \pm 0.07 \mathrm{a}$ & $1.28 \pm 0.06 \mathrm{a}$ & $1.12 \pm 0.11 \mathrm{a}$ & $0.97 \pm 0.06 \mathrm{~b}$ & $0.03 \pm 0.00 \mathrm{c}$ & $0.07 \pm 0.01 \mathrm{c}$ & $0.08 \pm 0.01 \mathrm{c}$ & $0.09 \pm 0.01 \mathrm{c}$ & $0.12 \pm 0.02 \mathrm{c}$ \\
\hline LMA, $\mathrm{g} \mathrm{m}^{-2}$ & $36.2 \pm 1.2 \mathrm{~d}$ & $34.0 \pm 16 \mathrm{~d}$ & $42.2 \pm 1.6 \mathrm{c}$ & $42.3 \pm 1.8 \mathrm{c}$ & $39.3 \pm 1.8 \mathrm{~d}$ & $44.4 \pm 2.6 \mathrm{bc}$ & $47.1 \pm 1.3 \mathrm{bc}$ & $49.2 \pm 2.4 \mathrm{~b}$ & $56.3 \pm 2.9 \mathrm{a}$ & $59.9 \pm 1.4 \mathrm{a}$ \\
\hline$A_{\mathrm{n}}, \mu \mathrm{mol} \mathrm{m} \mathrm{m}^{-2} \mathrm{~s}^{-1}$ & $13.5 \pm 0.6 \mathrm{a}$ & $11.7 \pm 0.8 \mathrm{~b}$ & $12.4 \pm 0.7 \mathrm{ab}$ & $12.4 \pm 0.45 \mathrm{ab}$ & $14.0 \pm 0.4 \mathrm{a}$ & $0.36 \pm 0.05 \mathrm{~d}$ & $1.55 \pm 0.31 \mathrm{~cd}$ & $1.33 \pm 0.19 \mathrm{~cd}$ & $2.00 \pm 0.11 \mathrm{c}$ & $1.53 \pm 0.27 \mathrm{~cd}$ \\
\hline $\mathrm{Tr}, \mathrm{mmol} \mathrm{m} \mathrm{m}^{-2} \mathrm{~s}^{-1}$ & $1.93 \pm 0.1 \mathrm{a}$ & $1.69 \pm 0.16 \mathrm{a}$ & $1.78 \pm 0.20 \mathrm{a}$ & $1.69 \pm 0.06 \mathrm{a}$ & $2.01 \pm 0.07 \mathrm{a}$ & $0.57 \pm 0.10 \mathrm{c}$ & $0.69 \pm 0.07 \mathrm{cb}$ & $0.63 \pm 0.04 \mathrm{c}$ & $0.92 \pm 0.07 \mathrm{~b}$ & $0.84 \pm 0.13 b c$ \\
\hline $\mathrm{N}, \mathrm{g} \mathrm{kg}^{-1}$ & $28.0 \pm 3.4 \mathrm{~b}$ & $40.9 \pm 2.2 \mathrm{a}$ & $30.3 \pm 5.5 \mathrm{ab}$ & $28.7 \pm 3.9 b$ & $27.4 \pm 2.8 \mathrm{~b}$ & 33.7 & 16.0 & 14.1 & 9.5 & 17.0 \\
\hline $\mathrm{P}, \mathrm{g} \mathrm{kg}^{-1}$ & $2.1 \pm 0.4 \mathrm{~b}$ & $3.4 \pm 1.0 \mathrm{a}$ & $2.6 \pm 0.6 \mathrm{ab}$ & $2.1 \pm 0.3 b$ & $2.9 \pm 0.3 \mathrm{ab}$ & 1.3 & 1.2 & 1.7 & 0.8 & 1.6 \\
\hline $\mathrm{K}, \mathrm{g} \mathrm{kg}^{-1}$ & $14.6 \pm 2.0 \mathrm{a}$ & $16.6 \pm 1.6 \mathrm{a}$ & $17.1 \pm 1.7 \mathrm{a}$ & $14.3 \pm 0.7 \mathrm{a}$ & $15.7 \pm 2.5 \mathrm{a}$ & 10.5 & 8.4 & 8.7 & 8.0 & 9.1 \\
\hline $\mathrm{Ca}, \mathrm{g} \mathrm{kg}^{-1}$ & $11.8 \pm 0.5 \mathrm{~b}$ & $14.0 \pm 1.1 \mathrm{a}$ & $11.5 \pm 0.5 \mathrm{~b}$ & $10.4 \pm 0.2 \mathrm{bc}$ & $9.5 \pm 0.7 \mathrm{c}$ & 13.4 & 15.8 & 12.8 & 12.1 & 11.6 \\
\hline $\mathrm{Mg} \mathrm{g} \mathrm{kg}^{-1}$ & $8.4 \pm 1.0 \mathrm{ab}$ & $9.7 \pm 0.5 \mathrm{a}$ & $8.2 \pm 0.6 \mathrm{abc}$ & $6.7 \pm 0.4 \mathrm{bc}$ & $6.3 \pm 0.3 \mathrm{c}$ & 5.4 & 5.9 & 5.2 & 4.6 & 3.9 \\
\hline $\mathrm{Fe}, \mathrm{mg} \mathrm{kg}^{-1}$ & $99.2 \pm 16.7 \mathrm{a}$ & $92.8 \pm 8.4 \mathrm{a}$ & $82.6 \pm 2.5 \mathrm{a}$ & $84.4 \pm 5.8 \mathrm{a}$ & $90.0 \pm 9.8 \mathrm{a}$ & 2077 & 1300 & 378 & 493 & 304 \\
\hline $\mathrm{Mn}, \mathrm{mg} \mathrm{kg}^{-1}$ & $954 \pm 37 a$ & $365 \pm 137 b$ & $196 \pm 13.4 b c$ & $116 \pm 27 \mathrm{c}$ & $224 \pm 10.0 \mathrm{bc}$ & 960 & 203 & 134 & 90 & 220 \\
\hline $\mathrm{Na}, \mathrm{g} \mathrm{kg}^{-1}$ & $1.02 \pm 0.1 \mathrm{c}$ & $2.0 \pm 0.2 \mathrm{c}$ & $3.7 \pm 0.3 b$ & $3.8 \pm 0.3 b$ & $6.8 \pm 0.7 \mathrm{a}$ & 3.7 & 7.9 & 9.0 & 10.7 & 14.9 \\
\hline PNUE, $\mu \mathrm{mol} \mathrm{CO} 2 \mathrm{~g}^{-1} \mathrm{~N} \mathrm{~s}^{-1}$ & $18.2 \pm 3.1 \mathrm{~d}$ & $7.8 \pm 09 \mathrm{c}$ & $11.0 \pm 2.4 \mathrm{bc}$ & $11.1 \pm 2.3 \mathrm{bc}$ & $12.0 \pm 0.5 \mathrm{ab}$ & $0.3 \pm 0.0 \mathrm{~d}$ & $1.9 \pm 0.3 \mathrm{~d}$ & $1.9 \pm 0.3 \mathrm{~d}$ & $3.9 \pm 0.2 \mathrm{~d}$ & $1.5 \pm 0.3 \mathrm{~d}$ \\
\hline PPUE, $\mu \mathrm{mol} \mathrm{CO} 2 \mathrm{~g}^{-1} \mathrm{P} \mathrm{s}^{-1}$ & $261 \pm 76 \mathrm{a}$ & $91.4 \pm 6 \mathrm{bc}$ & $136 \pm 35 \mathrm{~b}$ & $149 \pm 25 b$ & $112 \pm 5 b$ & $7 \pm 1 \mathrm{~d}$ & $50 \pm 7 \mathrm{~cd}$ & $15 \pm 2 \mathrm{~d}$ & $44 \pm 24 \mathrm{~cd}$ & $16 \pm 3 d$ \\
\hline PKUE, $\mu \mathrm{mol} \mathrm{CO} 2 \mathrm{~g}^{-1} \mathrm{~K} \mathrm{~s}^{-1}$ & $\begin{array}{c}0.028 \pm 0.004 \\
\mathrm{a}\end{array}$ & $\begin{array}{c}0.020 \pm 0.002 \\
\mathrm{bc}\end{array}$ & $0.018 \pm 0.002 \mathrm{c}$ & $\begin{array}{c}0.024 \pm 0.001 \\
\mathrm{ab}\end{array}$ & $\begin{array}{c}0.023 \pm 0.005 \\
a b c\end{array}$ & $\begin{array}{c}0.001 \pm 0.000 \\
\mathrm{~d}\end{array}$ & $\begin{array}{c}0.004 \pm 0.001 \\
\mathrm{~d}\end{array}$ & $\begin{array}{c}0.003 \pm 0.001 \\
\mathrm{~d}\end{array}$ & $\begin{array}{c}0.005 \pm 0.000 \\
\mathrm{~d}\end{array}$ & $\begin{array}{c}0.005 \pm 0.000 \\
\mathrm{~d}\end{array}$ \\
\hline PCaUE, $\mu \mathrm{mol} \mathrm{CO} 2 \mathrm{~g}^{-1} \mathrm{Ca} \mathrm{s}^{-1}$ & $\begin{array}{c}0.033 \pm 0.002 \\
\mathrm{a}\end{array}$ & $0.023 \pm 0.001 \mathrm{c}$ & $\begin{array}{c}0.026 \pm 0.002 \\
b c\end{array}$ & $0.028 \pm 0.003 b$ & $0.035 \pm 0.003 \mathrm{a}$ & $\begin{array}{c}0.002 \pm 0.000 \\
\mathrm{~d}\end{array}$ & $\begin{array}{c}0.002 \pm 0.000 \\
\mathrm{~d}\end{array}$ & $\begin{array}{c}0.002 \pm 0.000 \\
\mathrm{~d}\end{array}$ & $\begin{array}{c}0.003 \pm 0.000 \\
\mathrm{~d}\end{array}$ & $\begin{array}{c}0.002 \pm 0.000 \\
\mathrm{~d}\end{array}$ \\
\hline $\begin{array}{l}\mathrm{PMgUE}, \mu \mathrm{mol} \mathrm{CO} \mathrm{CO}_{2} \mathrm{~g}^{-1} \mathrm{Mg} \\
\mathrm{s}^{-1}\end{array}$ & $\begin{array}{c}0.048 \pm 0.006 \\
\mathrm{a}\end{array}$ & $0.033 \pm 0.002 \mathrm{c}$ & $\begin{array}{c}0.037 \pm 0.004 \\
\mathrm{bc}\end{array}$ & $\begin{array}{c}0.044 \pm 0.003 \\
\mathrm{ab}\end{array}$ & $0.052 \pm 0.007 \mathrm{a}$ & $\begin{array}{c}0.002 \pm 0.001 \\
\mathrm{~d}\end{array}$ & $\begin{array}{c}0.005 \pm 0.001 \\
\mathrm{~d}\end{array}$ & $\begin{array}{c}0.005 \pm 0.001 \\
\mathrm{~d}\end{array}$ & $\begin{array}{c}0.008 \pm 0.000 \\
\mathrm{~d}\end{array}$ & $\begin{array}{c}0.007 \pm 0.001 \\
\mathrm{~d}\end{array}$ \\
\hline PFeUE, $\mu \mathrm{mol} \mathrm{CO} 2 \mathrm{~g}^{-1} \mathrm{Fe} \mathrm{s}^{-1}$ & $4.16 \pm 0.58 \mathrm{a}$ & $3.42 \pm 0.23 \mathrm{~b}$ & $3.60 \pm 0.16 \mathrm{ab}$ & $3.52 \pm 0.356 \mathrm{ab}$ & $3.74 \pm 0.52 \mathrm{ab}$ & $0.00 \pm 0.00 \mathrm{c}$ & $0.02 \pm 0.00 \mathrm{c}$ & $0.07 \pm 0.01 \mathrm{c}$ & $0.08 \pm 0.00 \mathrm{c}$ & $0.08 \pm 0.01 \mathrm{c}$ \\
\hline $\begin{array}{l}\mathrm{PMnUE}, \mu \mathrm{mol} \mathrm{CO} \mathrm{CO}_{2} \mathrm{~g}^{-1} \mathrm{Mn} \\
\mathrm{s}^{-1}\end{array}$ & $0.40 \pm 0.02 \mathrm{df}$ & $1.13 \pm 0.27 \mathrm{c}$ & $1.53 \pm 0.12 b$ & $2.74 \pm 0.27 \mathrm{a}$ & $1.46 \pm 0.15 b$ & $0.01 \pm 0.00 \mathrm{f}$ & $0.15 \pm 0.02 \mathrm{df}$ & $0.21 \pm 0.03 \mathrm{df}$ & $0.42 \pm 0.02 \mathrm{~d}$ & $0.11 \pm 0.02 \mathrm{f}$ \\
\hline PNaUE, $\mu \mathrm{mol} \mathrm{CO} 2 \mathrm{~g}^{-1} \mathrm{Na} \mathrm{s}^{-1}$ & $\begin{array}{c}0.440 \pm 0.040 \\
\mathrm{a}\end{array}$ & $0.160 \pm 0.020 \mathrm{~b}$ & $0.080 \pm 0.010 \mathrm{c}$ & $0.080 \pm 0.020 \mathrm{c}$ & $0.050 \pm 0.010 \mathrm{c}$ & $\begin{array}{c}0.003 \pm 0.001 \\
\mathrm{~d}\end{array}$ & $\begin{array}{c}0.004 \pm 0.001 \\
\mathrm{~d}\end{array}$ & $\begin{array}{c}0.003 \pm 0.001 \\
\mathrm{~d}\end{array}$ & $\begin{array}{c}0.004 \pm 0.000 \\
\mathrm{~d}\end{array}$ & $\begin{array}{c}0.002 \pm 0.000 \\
\mathrm{~d}\end{array}$ \\
\hline WUE, $\mu \mathrm{mol} \mathrm{CO} \mathrm{CO}_{2} \mathrm{mml} \mathrm{H}_{2} \mathrm{O}$ & $7.0 \pm 0.2 \mathrm{a}$ & $6.8 \pm 0.4 \mathrm{a}$ & $7.2 \pm 0.5 \mathrm{a}$ & $7.3 \pm 0.1 \mathrm{a}$ & $7.0 \pm 0.3 \mathrm{a}$ & $0.7 \pm 0.1 \mathrm{c}$ & $2.2 \pm 0.2 \mathrm{~b}$ & $2.1 \pm 0.2 \mathrm{~b}$ & $2.3 \pm 0.2 b$ & $1.9 \pm 0.3 \mathrm{~b}$ \\
\hline
\end{tabular}

$\mathrm{DM}$, dry mass; LMA, leaf mass per area; $A_{\mathrm{n}}$, area-based net $\mathrm{CO}_{2}$ assimilation rate; $\mathrm{Tr}$, transpiration rate; PNUE (PPUE, PKUE, PCaUE, PMgUE, PFeUE, PMnUE, PNaUE)

photosynthetic $\mathrm{N}$ (P, K, Ca, Mg, Fe, Mn, Na) use efficiency; WUE, water use efficiency. 


\subsection{Photosynthetic Water Use Efficiency}

The decline of nutrient availability caused a decrease of photosynthetic WUE for the cucumber seedlings (Table 1). The WUE value was significantly altered by both LS application and nutrient availability $(p<0.05)$. The LS effect on WUE was stronger under LNA than the SNA condition. So, for the LNA seedlings, the WUE values were, on average, 2.3 times higher in the LS seedlings than in OLS ones.

\section{Discussion}

In this study, we sought to understand how LS application affects plant physiological state, particularly nutrient use efficiency for the photosynthetic processes. Therefore, we quantified the effects of soil nutrient availability on nutrient use efficiency of $C$. sativus to understand whether the response of these parameters to LS depends on soil nutrient conditions. The impact of nutrient availability on plant physiological traits was much stronger than the LS impact.

The plant biomass was positively, and LMA was negatively correlated with the leaf nutrient content, except the Fe and Mn concentration. Dramatically high levels of Fe under LNA and Mn under both SNA and LNA may be caused by the low $\mathrm{pH}$ of the soil under the study, which might increase the localized availability of Fe and Mn for plants. Iron toxicity reduces root development and plant growth [12], so the high concentration of Fe in LNA seedling can be the main reason for plant growth depression (Table 1). The high Mn concentrations found in this study is considered to be toxic for many species, including cucumber. Since LS application caused a decrease in leaf Mn, as well as, Fe, probably, due to an LS-related decrease in soil acidity, it could be assumed as Mn and Fe detoxifier. But further research needs to examine this statement.

With the decline in nutrient availability, the LMA of cucumber seedling increased, which is consistent with the earlier findings demonstrating that species grown in nutrient poor environments tend to have high LMA [13]. The LS application increased LMA regardless of the nutrient availability for the seedlings (Table 1). Our results demonstrated that the high LMA of LNA seedlings is associated with low nutrient use efficiency, is according to studies that have shown that high-LMA leaves tend to have low PNUE [14]. Since the decline in nutrient availability caused the significant decrease in the $A_{\mathrm{n}}$ rate and biomass accumulation, but not leaf $\mathrm{N}$ content, it can be assumed that the majority of leaf $\mathrm{N}$ of LNA seedlings was not connected with the photosynthetic processes. For the seedlings grown under SNA, the LS application decreased photosynthetic nutrient use efficiency of most elements, except $\mathrm{Mn}$. It was connected with the decrease of $A_{\mathrm{n}}$ and/or increase of element content per unite leaf area. The reduction of photosynthetic activity of SNA seedlings grown on the soil with low LS content (1LS) could be caused by an increase in N allocation to leaf non-photosynthesis structures and/or shift of $\mathrm{N}$ to $\mathrm{P}$ ratio to $\mathrm{P}$ deficit. The positive effect of LS on nutrient use efficiency was found only for Mn, and it was associated with LS-related decrease of Mn content per unit leaf area. The significant decrease of PNaUE was strongly correlated with the increase of leaf $\mathrm{Na}$ content for seedlings grown on the soil with LS.

It is well documented that the mineral-nutrient status of plants plays a critical role in water use efficiency [15]. Our results are in agreement with the findings that plant nutrients are not only required for the photosynthetic process and plant growth but also can improve WUE. In contrast to studies suggesting a trade-off relationship between PNUE and WUE, in this study photosynthetic efficiency of using of most studied elements decreased, as well, as WUE following the decline in nutrient availability for plants. The LS-related increase of WUE at the leaf level of LNA cucumber seedlings may have been due to an increased $\mathrm{CO}_{2}$ assimilation rate.

\section{Conclusions}

The impact of nutrient availability on plant physiological traits of cucumber seedlings was stronger than the lignosulfonate impact. The decline of nutrient availability affected seedlings 
The 1st International Electronic Conference on Plant Science, 1-15 December 2020 growth and photosynthesis more than leaf nutrient content, excluding leaf Fe concentration. Moreover, the decline of nutrient availability increased leaf mass per area and decreased the $\mathrm{CO}_{2}$ assimilation rate, photosynthetic nutrient and water use efficiency. The nutrient availability affected the seedling's response to lignosulfonate. Whereas lignosulfonate decreased nutrient use efficiency, except Mn, under sufficient nutrient availability, it slightly improved efficiency under low nutrient availability, but this impact was not successful to eliminate the negative effects of soil nutrient deficiency on cucumber seedlings.

Author Contributions: E.I. designed and performed the experiments, analyzed the data, wrote the paper; S.C. wrote the paper; M.J. conceived the experiments. All authors have read and agreed to the published version of the manuscript.

Acknowledgments: Experimental facilities for this study were offered by the Core Facility of the Karelian Research Centre of the Russian Academy of Sciences. The study was supported by state order No. 0218-2019-0074, and partly supported by the Russian Foundation for Basic Research No. 19-29-05174.

Conflicts of Interest: The authors declare no conflict of interest. The founding sponsors had no role in the design of the study; in the collection, analyses, or interpretation of data; in the writing of the manuscript, and in the decision to publish the results.

\section{Abbreviations}

The following abbreviations are used in this manuscript:

RAS Russian Academy of Science

LS Lignosulfonate

PPFD Photosynthetic photon flux density

SNA Sufficient nutrient availability

LNA Low nutrient availability

LMA Leaf mass area

PNUE Photosynthetic N use efficiency

PPUE Photosynthetic P use efficiency

PKUE Photosynthetic K use efficiency

PCaUE Photosynthetic Ca use efficiency

PMgUE Photosynthetic Mg use efficiency

PFeUE Photosynthetic Fe use efficiency

PMnUE Photosynthetic Mn use efficiency

PNaUE Photosynthetic Na use efficiency

WUE Photosynthetic water use efficiency

\section{References}

1. Krasilnikov, P.V. Stable carbon compounds in soils: Their origin and functions. Eurasian Soil Sci. 2015, 48, 997-1008, doi:10.1134/S1064229315090069.

2. Butphu, S.; Rasche, F.; Cadisch, G.; Kaewpradit, W. Eucalyptus biochar application enhances Ca uptake of upland rice, soil available $\mathrm{P}$, exchangeable $\mathrm{K}$, yield, and $\mathrm{N}$ use efficiency of sugarcane in a crop rotation system. J. Plant Nutr. Soil Sci. 2020, 183, 58-68, doi:10.1002/jpln.201900171.

3. Ikkonen, E.; Chazhengina, S.; Butilkina, M.; Sidorova, V. Physiological response of onion (Allium cepa L.) seedlings to shungite application under two soil water regimes. Acta Physiol. Plant. in press.

4. Carrasco, J.; Kovács K.; Czech, V.; Fodor, F.; Lucena, J.J.; Vértes A.; Hernández-Apaolaza, L. Influence of $\mathrm{pH}$, iron source, and $\mathrm{Fe} /$ ligand ratio on iron speciation in lignosulfonate complexes studied using Mössbauer spectroscopy. Implications on their fertilizer properties. J. Agric. Food Chem. 2012, 60, 3331-3340, doi:10.1021/jf204913s.

5. Jiao, G.; Xu, Q.; Cao, S.; Peng, P.; She, D. Controlled-release fertilizer with lignin used to trap urea/hydroxymethylurea/urea-formaldehyde polymers. BioResources 2018, 13, 1711-1728, doi:10.1016/B978-1-4832-3298-0.50008-4. 
The 1st International Electronic Conference on Plant Science, 1-15 December 2020

6. Islas-Valdez, S.; López-Rayo, S.; Hristov-Emilov, H.; Hernández-Apaolaza, L.; Lucena, J.J. Assessing metal-lignosulfonates as fertilizers using gel filtration chromatography and high-performance size exclusion chromatography. Int. J. Biol. Macromol. 2020, 142, 163-171, doi:10.1016/j.ijbiomac.2019.09.088.

7. Liu, Q.; Deng, Y.; Tang, J.; Chen, D.; Li, X.; Lin, Q.; Yin, G.; Zhang, M.; Hu, H. Potassium lignosulfonate as a washing agent for remediating lead and copper co-contaminated soils. Sci. Total Environ. 2019, 658, 836-842, doi:10.1016/j.scitotenv.2018.12.228.

8. Rodríguez-Lucena, P.; Tomasi, N.; Pinton, R.; Hernández-Apaolaza, L.; Lucena, J.J.; Stefano Cesco, S. Evaluation of 59Fe-lignosulfonates complexes as Fe-sources for plants. Plant Soil. 2009, 325, 53-63, doi:10.1007/s11104-009-0091-1.

9. Docquier, S.; Kevers, C.; Lambe, P.; Gaspar, T.; Dommes, J. Beneficial use of lignosulfonates in in vitro plant cultures: Stimulation of growth, of multiplication and of rooting. Plant Cell Tiss. Organ Cult. 2007, 90, 285-291, doi:10.1007/s11240-007-9267-7.

10. Stapanian, M.A.; Shea, D.W. Lignosulfonates: Effects on plant growth and survival and migration through the soil profile. Int. J. Environ. Studies. 1986, 27, 45-56, doi:10.1080/00207238608710276.

11. Ertani, A.; Francioso, O.; Tugnoli, V.; Righi, V.; Nardi, S. Effect of Commercial Lignosulfonate-Humate on Zea mays L. Metabolism. J. Agric. Food Chem. 2011, 59, 11940-11948, doi:10.1021/jf202473e.

12. Dorlodot, S.; Lutts, S.; Bertin, P. Effects of ferrous iron toxicity on the growth and mineral composition of an interspecific rice. J. Plant Nutrit. 2005, 28, 1-20, doi:10.1081/PLN-200042144.

13. Chapin, F.S. The mineral nutrition of wild plants. Annu. Rev. Ecol. Evol. Syst. 1980, 11, 233-260, doi:10.1146/annurev.es.11.110180.001313.

14. Poorter, H.; Evans, J.R. Photosynthetic nitrogen-use effciency of species that differ inherently in specic leaf area. Oecologia 1998, 116, 26-37, doi:10.1007/s004420050560.

15. Waraich, E.A.; Ahmad, R.; Ashraf, M.Y.; Saifullah; Ahmad, M. Improving agricultural water use efficiency by nutrient management in crop plants. Acta Agric. Scand. B Soil. Plant Sci. Acta Agric. 2011, 61, 291-304, doi:10.1080/09064710.2010.491954.

Publisher's Note: MDPI stays neutral with regard to jurisdictional claims in published maps and institutional affiliations.

(C) 2020 by the authors. Licensee MDPI, Basel, Switzerland. This article is an open access article distributed under the terms and conditions of the Creative Commons Attribution (CC BY) license (http://creativecommons.org/licenses/by/4.0/). 